\title{
Konsepsi Hak Menguasai Oleh Negara Atas Sumberdaya Agraria
}

\author{
Mukmin Zakie
}

\begin{abstract}
Abstrak
The ideal aspiration which exists in the Authority Rights of a State conception is to place the State as a party who has the authority to regulate the use of the State property to the welfare of the society. The Aspiration requires a neutral State which is free from the interest of others, except the interest of social welfare. However, in the reality, State is not neutral from intervention of individual interest or a group of people interest on behalf of the public interest. Thus, the promise of the State to grant welfare to the society is merely on the normative level.
\end{abstract}

\section{Pendahuluan}

Konsep Hak Menguasai Negara (HMN) pada mulanya diperkenalkan melalui Pasal 33 ayat (3) Undang-Undang Dasar 1945 yang menyatakan bahwa bumi, air dan kekayaan alam yang terkandung di dalamnya dikuasai oleh negara dan dipergunakan untuk sebesarbesar kemakmuran Rakyat. Di dalam penjelasannya menyatakan bumi, air, dan kekayaan alam yang terkandung dalam bumi adalah pokok-pokok kemakmuran rakyat sebab itu harus dikuasai oleh Negara dan dipergunakan untuk sebesar-besar kemakmuran rakyat.

Lima belas tahun kemudian, tepatnya pada tanggal 24 September 1960 dengan diundangkannya Undang-Undang Nomor 5 tahun 1960 tentang Peraturan Dasar Pokokpokok Agraria kemudian lebih dikenal dengan Undang-Undang Pokok Agraria, konsep hak menguasai negara ini diperinci dan diperluas pengertiannya.'

Sesuai dengan Penjelasan UUPA maka Hak Menguasai Negara tersebut meliputi atas bumi, air dan ruang angkasa, jadi baik yang sudah ada hak seseorang maupun yang tidak belum ada. Kekuasaan negara mengenai tanah yang sudah dipunyai orang dengan sesuatu hak dibatasi oleh isi dari hak itu, artinya sampai seberapa jauh negara memberi kekuasaan kepada yang mempunyai hak untuk menggunakan haknya, sampai disitulah

${ }^{1}$ Maria R. Ruwiastuti, Noer Fauzi, Dianto Bachriadi, Penghancuran Hak Masyarakat Adat Atas Tanah, (KPA, Bandung, 1997) hlm 96 
batas kekuasaan negara tersebut. ${ }^{2}$

Jelas kiranya, bahwa dalam hubungannya dengan bumi, air dan ruang angkasa, termasuk kekayaan alam yang terkandung di dalamnya, selaku organissasi kekuasaan seluruh rakyat, Negara bertindak dalam kedudukannya sebagai Kuasa dan Petugas Bangsa Indonesia.

Dalam melaksanakan tugas tersebut ia merupakan organisasi kekuasaan rakyat yang tertinggi. ${ }^{3} \mathrm{Hal}$ ini disebabkán karena Hak Menguasai dari Negara menupakan pelimpahan tugas kewenangan Bangsa Indonesia, yang dilakukan oleh wakil-wakil Bangsa Indonesia pada waktu menyusun Undang-Undang Dasar 1945 dan membentuk Negara Republik Indonesia pada tanggal 18 Agustus $1945 .{ }^{4}$

Dalam konstruksi hukumnya dapat dianalogikan sebagai perjanjian pemberian kuasa dari Bangsa Indonesia kepada Negara Indonesia, selaku pihak pemberi kuasa adalah Bangsa Indonesia sebagai pemegang hak penguasaan tertinggi atas bumi, air, ruang angkasa dan kekayaan alam terkandung di dalamnya dalam wilayah Republik Indonesia seperti dinyatakan dalam Pasal 1 ayat (1) UUPA disebut sebagai Hak Bangsa. Sedangkan pihak penerima kuasa adalah Negara Indonesia sebagai organisasi kekuasaan seluruh rakyat Indonesia.

Dalam perkembangannya, pemberian kuasa dari rakyat/bangsa Indonesia kepada Negara, bukan menjadikan rakyat semakin makmur tetapi justru semakin terpuruk atas penguasaan sumber daya agraria.karena dalam kenyataannya negara diboncengi oleh sejumlah kepentingan kelompok atau individu yang mengatasnamakan kepentingannya itu dengan kepentingan umum atau kepentingan rakyat atau kepentingan negara. Tentu saja hal ini bertentangan dengan cita-cita ideal yang terkandung di dalam konsepsi HMN.

\section{Antara Hak Menguasai Negara dan Domein Verklaring}

Dirumuskannya prinsip Hak Menguasai dari Negara (HMN) sesungguhnya dimaksudkan untuk menghapus dan mengganti azas Domein Verklaring yang diberlakukan di Hindia Belanda (Indonesia) pada zaman kolonial Belanda berdasarkan Pasal 1 Agrarisch Besluit yang diundangkan dalam S.1870-118.

Pemerintah kolonial Belanda melalui domein verklaring atas tanah yang berdasarkan Pasal 1 Agrarische Beslut 1870 menegaskan tanah-tanah yang tidak dapat dibuktikan kepemilikannnya adalah menjadi milik negara. ${ }^{5}$ Pernyataan itu, mempertegas adanya hubungan penguasaan sepenuh-penuhnya dari negara atas tanah (staat ter bechikking van de landsoiverheid). ${ }^{6}$ Makna domein yang demikian mengarah kepada eigendom negara atau negara sebagai pemilik (eigenaar) yang bersifat privaatrechtelijk.

Domein Verklaring ini mengandung hlm. 39

${ }^{2}$ A.P. Parlindungan, KomentarAtas Undang-Undang PokokAgraria, (PT. Mandar Maju, Bandung, 1991),

${ }^{3}$ Boedi Harsono, Hukum Agraria Indonesia, Sejarah Pembentukan Undang-undang Pokok Agraria, Isi dan Pelaksanaannya, Jilid 1, Cetakan Ketujuh, Edisi Revisi 1997, (Djambatan, Bandung, 1997), hlm 218.

${ }^{4} \mathrm{Ibid}$. HIm. 243

${ }^{5}$ Abrar Saleng, Hukum Pertambangan, (UII Press, Yogyakarta, 2004), hlm. 53

${ }^{6}$ Ronald Z. Titahelu, "Penetapan Azas-Azas Hukum Umum Dalam Penggunaan Tanah Untuk SebesarBesar Kemakmuran Rakyat", Desertasi, (PPs.UNAIR, Surabaya, 1993), hlm 90. 
pengertian sebagai hak milik mutlak negara kolonial Hindia Belanda, untuk itu maka pemerintah kolonial bisa menjual tanah-tanah di Indonesia kepada siapa saja, bahicn kepada warga negara asing, yang pada masa lalu menimbulkan banyaknya tanah-tanah partikelir dan tuan-tuan tanah dengan hak yang sangat luas dan dapat diibaratkan seperti adanya negara (tanah-tanah partikelir) dalam negara (Pemerintahan Kolonial Hindia Belanda). ${ }^{7}$

Cita-cita ideal yang terkandung di dalam konsepsi HMN adalah menempatkan Negara sebagai sentral yang mengatur pemanfaatan kekayaan negeri untuk kemakmuran rakyat. Untuk mencapai cita-cita ini dengan tegas mengemukakan prasyarat adanya sebuah negara yang kuat, karena akan menjadi sentral atau pusat dari segala hal - paling tidak dalam hal ini dengan segala persoalan keagrariaan. ${ }^{8}$ Di sisi lain, cita-cita ini juga mensyaratkan adanya suatu bentuk Negara yang netral, bebas dari kepentingan yang lain - kecuali kepentingan mensejahterakan rakyat. ${ }^{9}$ Atau dalam istilah Kuntowijoyo, prasyarat itu adalah sebuah Negara Budiman. ${ }^{10}$ Pada kenyataannya negara kemudian diboncengi oleh sejumlah kepentingan kelompok atau individu yang mengatasnamakan kepentingannya itu dengan kepentingan umum atau kepentingan rakyat atau kepentingan negara.

Kurang lebih setelah enam tahun diundangkannya UUPA, ketika pemerintahan Soekarno (Orde Lama) sedang berupaya menjalankan sejumlah amanat yang dikandung UUPA untuk mensejahterakan rakyat dan membebaskan rakyat Indonesia dari penindasan oleh manusia terhadap sesama manusia (explotation de l'homme pour I'homme), khususnya melalui program Land Reform sebagai awalan, konflik kepentingan atas sumber-sumber agraria di Indonesia dan

\section{${ }^{7}$ Noer Fauzl; Petani \& Penguasa, Dinamika Perjalanan PolitikAgraria Indonesia, (Insist Press, KPAdan} Pustaka Pelajar, Yogyakarta, 1999), hlm. 72.

${ }^{8} \mathrm{Konsepsi} \mathrm{negara} \mathrm{yang} \mathrm{mengatasi} \mathrm{warganya} \mathrm{berasal} \mathrm{dari} \mathrm{pandangan} \mathrm{Hegel} \mathrm{yang} \mathrm{memandang} \mathrm{negara}$ sebagai penjelmaan dari ide universal, yaitu menciptakan masyarakat yang lebih baik. Karena itu Negara perlu memperoleh kekuasaan yang besar agar bisa bekerja untuk mewujudkan ide besar dan universal tersebut. Tetapi perlu dicatat, dalam pandangan Hegel, kekuasaan negara yang besar tersebut diabdikan bagi kebaikan masyarakat, dengan membimbing masyarakat yang sekarang menuju kemasyarakat yang sempurna di masa datang. Ini adalah tugas sejarah dari Negara. Negara modem, menurut Hegel, memiliki hakuntukmemaksakan keinginannya kepada warga negara. Karena itu, negara harus dipatuhi oleh warganya, bukan sebaliknya. Sebagai lembaga yang mengatakan masyarakat, negara lah yang tahu segala hal yang baik bagi masyarakat secara keseluruhan. Pandangan Hegelian yang menegaskan perlunya suatu negara yang kuat diteruskan oleh pandangan negara organis, yang melihat negara sebagai lembaga yang memiliki kemauannya sendiri yang mandiri. Noer Fauzi, Dianto Bachriadi, Hak Menguasai dari Negara (HMN), Persoalan Sejarah yang Harus Diselesaikan, Kertas Posisi KPA (Position Paper) No.004/1998, Ctk. Ke-2 tahun 200. HIm. 3

${ }^{9}$ Konsep negara yang netral, khususnya menjalankan misi mensejahterakan masyarakat sebagai kompromi dari berbagai kepentingan, merupakan konsep kaum pluralis. Kaum pluralis memang melihat negara adalah sebuah alat untuk memperjuangkan kepentingan, tetapi kepentingan itu adalah kepentingan bersama dari kelompok-kelompok yang ada dalam masyarakat yang membangun kompromi antara mereka. Ibid.

${ }^{10}$ Kuntowijoyo, "Masalah Tanah dan Runtuhnya Mitos Negara Budiman", Makalah, Yogyakarta, 1992. dalam Noer Fauzi, ibid 
memdapatkan ruang konflik yang lebih besar di dalam konflik elite militer yang berujung pada peristiwa 1965-1966 (Gerakan 30 September oleh Partai Komunis Indonesia /PKI), dan jatuhnya rezim Orde Lama. Rezim yang menggantikannya, rezim Orde Baru (di bawah Soeharto), yang menyandarkan diri pada kelompok kapitalis internasional kemudian merubah orientasi pembangunan seperti yang telah diamanatkan oleh UUPA dengan praktik politik ekonomi dan politik hukum yang pada dasarnya tidak sehaluan dengan amanat UUPA yang populistik atau (Neo) Populistik."

Ironisnya, dengan menggunakan konsepsi HMN ini politik hukum agraria rejim Orde Baru mengembangkan proses marginalisasi posisi UUPA sebagai undang-undang induk (pokok), disatu sisi, dengan mengembangkan berbagai undang-undang pokok lainnya, seperti Ketentuan-ketentuan Pokok Kehutanan (Undang-Undang Nomor 5 tahun 1967), Ketentuan-ketentuan Pokok Pertambangan (Undang-undang Nomor 11 tahun 1967) dan sebagainya. Di sisi lain, sebagai konsekuensinya, muncullah "sektoralisme" kekuasaan dan administrasi negara dalam wujud departemendepartemen sektoral yang menjadi agen langsung dari pelaksanaan HMN tersebut. ${ }^{12}$

Dalam praktiknya, kedudukan negara yang dominan tersebut terbukti telah dimanfaatkan oleh pemerintahan dan pengusaha kroninya untuk mengejar pertumbuhan ekonomi dalam bentuk usaha-usaha peningkatan produktivitas, tanpa memberi rakyat peran memadai untuk berpartisipasi dalam penguasaan, peruntukan, pengelolaan dan pemanfaatan sumber-sumber agraria itu, serta menikmati hasilnya. ${ }^{13}$

\section{Pengertian Hak}

Istilah "hak" selalu tidak dapat dipisahkan dengan istilah hukum. Di dalam literatur hukum Belanda, kedua-duanya disebut dengan recht. Akan tetapi antara hak dan hukum dapat dibedakan dengan menggunakan istilah objektief recht dan subjektief recht. Van Apeldoorn ${ }^{14}$ mengartikan objektief recht dengan hukum objektif, yaitu peraturan hukum yang berlaku umum. Subjektief recht diartikan dengan hukum subjektif yaitu untuk menyatakan hubungan yang diatur oleh hukum objektif, berdasarkan mana yang satu mempunyai hak, dan yang lain mempunyai kewajiban terhadap sesuatu.

Selanjutnya ia menyatakan, biasanya orang mengartikan istilah subjektief recht dengan hak yang diberikan oleh hukum objektif. Hak atau wewenang di sini merupakan segi aktif dari hubungan hukum yang diatur oleh peraturan hukum. Setiap hubungan hukum senantiasa melahirkan hak pada satu pihak, dan kewajiban di lain pihak.

"Noer Fauzi, "Penghancuran Populisme dan Pembangunan Kapitalisme:Dinamika PolitikAgraria Indonesia Pasca Kolonia"l, dalam Dianto Bachriadi,dkk. et.al. Perubahan Politik. Sengketa, danAgenda Pembaruan Agraria di Indonesia : Reformasi Agraria, (KPA bekerjasama dengan Lembaga Penerbit Fakultas Ekonomi Universitas Indonesia, Jakarta, 1997), hlm. 67

12 Noer Fauzi, Dianto Bachriadi, Op Cit. HIm. 4

${ }^{13}$ Noer Fauzi, Restitusi Hak Atas Tanah, Mewujudkan Keadilan Agraria di Masa Transisi, Kertas Posisi KPA(Position Paper) No. 009/2001, KPA, Bandung, 2001. HIm. 5.

${ }^{14}$ van L.J. Apeldoorn, Pengantar IImu Hukum, terjemahan Oetarid Sadino, (Penerbit PT. Pradnya Paramita, Jakarta, 1978), hlm.55-58. 
Knottenbelt, seperti yang dikutip oleh Sudikno Merto-kusumo, ${ }^{15}$-mengemukakan bahwa hak itu memberikan kenikmatan dan keleluasaan kepada individu dalam melaksanakannya. Sedangkan kewajiban merupakan pembatasan dan beban, sehingga yang menonjol ialah segi aktif dalam hubungan hukum itu, yaitu hak. Kalau hukum sifatnya umum, karena berlakunya bagi setiap orang, maka hak dan kewajiban itu sifatnya individual, melekat pada individu.

Dalam hubungan ini, P. Scholten bemendapat bahwa keselunuhan sistem hukum perdata didasarkan pada subjectief recht. Sebaliknya Algra mengatakan bahwa objectief recht adalah dasar dari subjectief recht. ${ }^{16}$

Perbedaan pendapat antara Scholten dengan Algra, menurut Sudikno Mertokusumo terletak pada perbedaan sudut pandangan. Selanjutnya beliau menyatakan bahwa Algra melihat dari sudut daya kerjanya. Subjectief recht itu baru nyata setelah ditetapkan oleh objectief recht: saya berhak melakukan sesuatu karena hal itu ditetapkan oleh objectief recht. Hukum memerlukan terjadinya peristiwa. barulah memberi hak atau membebani kewajiban apabila peristiwa itu terjadi. Scholten melihat subjectief recht melekat pada setiap individu sejak dilahirkan sampai mati, jadi melihatnya secara historis teoretis, sedangkan Algra melihatnya secara positif operasional. ${ }^{17}$

Perbedaan pendapat antara Scholten dengan Algra itu, menunjukkan bahwa peraturan hukum menempati tempat yang sentral. Apabila satu dipandang, hak itu diperoleh individu semenjak lahir berarti peraturan hukum berperan sebagai melegalisasi hak-hak yang sudah dimiliki oleh individu. Sebaliknya jika dipandang, justru peraturan hukumlah yang memberikan hak kepada individu, maka individu tidak mempunyai hak apa pun kecuali jika ditetapkan oleh peraturan hukum. Berpegang pada satu pihak saja, tidak menunjukkan kenyataan yang sesungguhnya. Dari sudut inilah dapat dipahami apa yang dikemukakan oleh Sudikno Mertokusumo di atas.

Dalam setiap hak selalu terdapat empat unsur, yaitu subjek hukum, objek hukum, hubungan hukum yang mengikat pihak lain dengan kewajiban, dan perlindungan hukum.

Sudikno Mertokusumo selanjutnya membedakan dua macam hak, yaitu hak absolut dan hak relatif. Hak absolut memberi wewenang bagi pemegang untuk berbuat atau tidak berbuat, pada dasarnya dapat dilaksanakan terhadap siapa saja dan melibatkan setiap orang. Kalau ada hak absolut pada seseorang, maka ada kewajiban bagi setiap orang lain untuk'menghormati dan untuk tidak mengganggunya. Pada hak absolut pihak ketiga berkepentingan untuk mengetahui eksistensinya, sehingga memerlukan publisitas.

Berbeda dengan hak relatif yang merupakan hak yang berisi wewenang untuk menuntut hak yang hanya dimiliki seseorang terhadap orang-orang tertentu, sehingga hanya berlaku bagi orang-orang tertentu. Hak absolut terdiri dari hak absolut yang bersifat kebendaan

${ }^{15}$ Knottenbelt, Inleiding in het Nederlandse recht, dalam Sudikno Mertokusumo, Mengenal Hukum (Suatu Pengan-tar), (Liberty, Yogyakarta, 1986), hlm.39.

${ }^{16}$ P. Shcolten, Algemeen Deèl, dalam Sudikno Mertokusumo, ibid, him. 39.

${ }^{17}$ Algra, Rechtsingang, dalam Sudikno Mertokusumo, ibid, hlm. 40. 
dan hak absolutyang tidak bersifat kebendaan. ${ }^{1 \mathrm{~B}}$

Menurut Salmond, istilah hak bisa disifatkan kepada arti yang sempit dan arti yang luas. Hak dalam arti sempit, yaitu selalu berkolerasi dengan kewajiban. Sebutan hak sebetulnya meliputi semua pengertian yang termasuk di dalamnya masing-masing adalah; hak dalam arti sempit, kemerdekaan, kekuasaan, dan imunitas.

\section{Hak Penguasaan Atas Tanah}

Hak-hak penguasaan atas tanah pada umumnya, pada hakekatnya merupakan refleksi dari pandangan manusia terhadap dirinya sebagai manusia dalam hubungannya dengan pandangannya terhadap tanah. Pada umumnya pandangan terhadap manusia, ada yang menițik beratkan kepada manusia sebagai individu, dan ada pula yang menitik beratkan kepada manusia sebagai makhluk sosial. ${ }^{19}$

Pandangan manusia terhadap manusia telah melahirkan aliran-aliran hukum yang berkisar pada:

1. Individu atau perseorangan diberi tempat di bawah ma-syarakat.

2. Masyarakat diberi tempat di bawah perseorangan, dan

3. Masyarakat dan Individu pada tempat yang sejajar.

Pandangan yang pertama cenderung untuk menyangḱal adanya hak perseorangan.
Pandangan ini telah dikenal semenjak Plato sampai kepada Leon Duguit.

Pandangan kedua, menempatkan masyarakat di bawah individu, karena dipandang masyarakat berdasarkan kepada individu. Pandangan ini dikembangkan oleh kaum Stoa yang kemudian sampai menjadi dasar dari teori social contract dan pandangan rasionalisme hukum. Pandangan yang terakhir, mencoba mensintesiskan pandangan yang saling kontradiksi itu seperti yang dikembangkan oleh Hegel yang kemudian menjadi dasar bagi negara facis. ${ }^{20}$

Filsafat Barat tentang pergaulan hidup manusia pada umumnya berpangkal kepada pandangan individu otonom bebas, seperti yang dikemukakan oleh Soediman Kartohadiprodjo bahwa filsafat Barat tentang pergaulan hidup manusia berpangkal kepada pandangan individu otonom bebas, jadi masing-masing dengan kekuasaan penuh itu, kehidupan bersama untuk memperoleh pergaulan hidup yang merupakan kenyataan manusia dijumpai selalu hidup bersama itu, mendorong diadakannya organisasi dari kekuasaan yang terdapat pada masingmasing individu. Organisasi ini yang dinamakan negara, organisasi kekuasaan itu bertujuan agar tidak ada bentrokan-bentrokan antara individu-individu otonom yang hidup bersama. ${ }^{21}$

Hal yang sama juga dinyatakan oleh Moh. Koesnoe ${ }^{22}$ bahwa hukum Barat berpangkal pada pandangan bahwa seseorang itu adalah

${ }^{18}$ Sudikno Mertokusumo, ibid, hlm. 45-46.

19Notonegoro, Politik Hukum dan Pembangunan Agraria di Indonesia, Bina Aksara, Jakarta, 1984, hlm. 17

${ }^{20}$ Soetikno, Filsafat Hukum, Bagian I, (Pradnya Para-mita, Jakarta, 1976), Cet. 1, him. 48-49.

21Soediman Kartohadiprodjo, Membina Tata Kehidupan Poli-tik Berdasarkan Undang-undang Dasar 1945, (Alumni, Bandung, 1979), Cet.I, hlm. 4.

${ }^{22}$ Moh. Koesnoe, Catatan-catatan Terhadap Hukum Adat Dewasa Ini, (Airlangga University Press, Surabaya, 1979), hlm. 4. 
makhluk yang bebas atau merdeka dan sama satu dengan lainnya. Akibat dari pengalaman sebagai manusia yang hidup bersama dengan lain individu, maka setiap individu berusaha untuk sedapatnya mempertahankan kebebasannya atau kemerdekaannya itu, sehingga kebebasan atau kemerdekaan masing-masing dapat saling terjaga. Hal ini hanya dapat dihindari dengan mengadakan perjanjian masyarakat, dimana satu sama lain akan menghormati kemerdekaan masingmasing dalam berusaha untuk memenuhi kebutuhan dan kepentingan masing-masing yang beraneka ragam. Keadaan ini membawa adanya pembatasan-pembatasan dalam perjuangan para individu untuk memenuhi kepentingan masing-masing demi untuk terhindar dari keadaan yang merugikan individu itu sendiri. Pembatasan-pembatasan itu adalah pembatasan yang dalam intinya berpedomankan kepada cita-cita keadilan dan kepastian. Pembatasan-pembatasan demikian itu adalah pedoman hidup yang melindungi kepentingankepentingan. Dan untuk terselenggaranya kehidupan yang tertib dan damai, diperlukan adanya syarat-syarat yang menjamin terlaksananya pedoman hidup tersebut.

Pedoman hidup yang menetapkan syaratsyarat yang disertai dengan sanksi, disebut dengan hukum. Kehadiran hukum di dalam masyarakat di antaranya adalah untuk mengintegrasikan dan mengkoordinasikan kepentingan-kepentingan tersebut. P'engorganisasian kepentingankepentingan itu dilakukan dengan membatasi dan melindungi kepentingan tersebut. Hukum melindungi kepentingan seseorang dengan cara mengalokasikan suatu kekuasaan kepadanya untuk bertindak dalam rangka kepentingan tersebut.

Pengalokasian kekuasaan ini dilakukan secara terukur dalam arti ditentukan keluasan dan kedalamannya. Kekuasaan yang demikian itulah yang disebut sebagainak. Kekuasaan yang terletak di bidang publik disebut dengan kewenangan, sedang di bidang perdata disebut dengan kecakapan. ${ }^{23}$

Dalam pandangan hukum adat yang menjadi dasar dari hukum agraria nasional yang kini berlaku, yaitu yang berpangkal pada Pasal 33 ayat (3) Undang-undang dasar 1945 dan Undangundang PokokAgraria, para individu adalah bagian dari masyarakat yang masing-masing mempunyai fungsi demi untuk melangsungkan dan kelangsungan masyarakat. Kepentingan yang ada pada individu adalah bagian dari kepentingan masyarakat untuk melangsungkan dan kelangsungan hidup masyarakat itu sendiri. Kepentingan individu, telah mengarah kepada satu arah yaitu kesejahteraan kesatuan dan kelangsungan masyarakat atau persekutuannya. Setiap individu di dalam kesatuan itu bergerak berusaha sebagai pengabdian kepada keseluruhan kesatuan itu. ${ }^{24}$

Masyarakat menurut Soerjono Soekanto ditandai oleh beberapa ciri pokok. Pertama, adanya orang-orang yang hidup bersama. Secara pasti tidak ada ukuran dalam bentuk angka berapa jumlah orang yang hidup bersama itu untuk dapat disebut sebagai masyarakat. Kedua, bahwa orang-orang yang hidup bersama itu bercampur untuk waktu yang cukup lama. Mengenai waktu hidup bersama, tidak ada ukuran yang mutlak. Yang jelas sebagai salah satu akibatnya adalah

\footnotetext{
${ }^{23}$ Satjipto Rahardjo, Ilmu Hukum, (Alumni, Bandung, 1986), hlm. 93.

${ }^{24}$ Moh. Koesnoe, Op cit, hlm. 6
} 
timbul nilai-nilai dan norma yang mengatur perilaku kehidupan bersama tersebut. Ketiga, adanya suatu kesadaran dari masing-masing menganggap dirinya sebagai bagian dari suatu kesatuan yang lebih besar. Keempat, bahwa sebagai sistem kehidupan bersama, masyarakat menghasilkan kebudayaan. Kebudayaan tersebut merupakan hasil karya, cita dan rasa dari kehidupan bersama yang didasarkan kepada karsa. sebagai suatu proses, maka kebudayaan tidak mungkin dipisahkan dari masyarakat, demikian pula sebaliknya. ${ }^{25}$

Dalam masyarakat hukum adat, individu dipandang bukanlah sebagai dasar terbentuknya masyarakat. Demikian pula sebaliknya hak masyarakat bukaniah berdasarkan kepada hak-hak individu. Hak di dalam cara berpikir bangsa Indonesia, adalah hak-hak kemasyarakatan, artinya hak yang diberikan kepada individu berhubung dengan tugas dan fungsinya di dalam masyarakat. Masyarakat sebagai suatu persekutuan hukum mengharapkan agar individu itu akan menjalankan kekuasaan hukumnya itu sesuai dengan tujuan sosial. ${ }^{26}$

Di dalam hukum adat, hak-hak individu merupakan fungsi individualitas dari kekuasaan negara atau masyarakat. Dalam hubungannya dengan hak penguasaan atas tanah bagi masyarakat hukum Indonesia khususnya, maka hak masyarakat yang dikenal dengan "hak ulayat" merupakan dasar dan asal dari hak-hak yang dapat dipunyai oleh orang perseorangan. Tidak ada satupun dari hak-hak atas tanah yang dipunyai perseorangan yang berada di luar kungkungan hak ulayat. Semakin kuat hak orang perseorangan, maka pengaruh hak ulayat semakin lemah. Sebaliknya jika hakhak perseorangan melemah, maka hak ulayat semakin kuat. Apabila hak perseorangan hapus, maka hak ulayat pulih kembali.

Dalam pemikiran seperti itulah dapat dipandang benar dan tepat apa yang ditetapkan oleh Pasal 33 ayat (3) Undang-undang dasar 1945 dan pernyataan Pasal 1 ayat (2) serta Pasal 2 ayat (1) UUPA yang menempatkan. "hak menguasai negara" sebagai dasar dan asal dari semua hak-hak keagrariaan.

Dari kekuasaan negara atau masyarakat ini kemudian dikeluarkan kekuasaankekuasaan dalam ukuran yang lebih kecil, yang dalam bentuk, isi dan sifatnya beraneka ragam. Fungsi individualistis dari kekuasaan negara atau masyarakat, artinya fungsi untuk membuat anggota masyarakat dalam perseorangannya menjadi berada di dalam kemungkinan keadaan sejahtera. ${ }^{27}$

Hubungan antara hak ulayat dengan hak-hak perseorangan atau badan hukum di dalam literatur hukum adat dipergunakan istilah "hak ulayat mengembang dan mengempis". Istilah resmi yang dipakai oleh $\mathrm{K}$. Ng. Soebekti Poesponoto di dalam menterjemahkan buku Ter Haar, adalah "hak ulayat menguncup dan mengembang" bertimbal balik dengan tiada hentinya..$^{28}$

Konsep tentang hak ulayat ini sedikit

${ }^{25}$ Soerjono Soekanto, Sosiologi Hukum Dalam Masyara-kat,CV. Rajawali, Jakarta, 1982, hlm. 274-276.

${ }^{26}$ R. Soepomo, Hubungan Individu dan Masyarakat dalam Hukum Adat, (PT. Pradnya Paramita, Jakarta, 1970), hlm. 10.

${ }^{27}$ Moh. Koesnoe, Op cit, hlm. 72.

${ }^{28}$ Ter Haar, Asas-asas dan Susunan Hukum Adat, terjemahan K.Ng. Soebekti Poesponoto, (Pradnya Paramita, Jakarta, 1976), hlm.72. 
banyak diikuti oleh pembentuk Undangundang Pokok Agraria. Hal ini dapat dilihat pada Penjelasan Umum II angka (1) yang menyatakan bahwa dengan pengertian demikian maka hubungan bangsa Indonesia dengan bumi, air dan ruang angkasa Indonesia merupakan semacam hubungan hak ulayat yang diangkat pada tingkatan yang paling atas, yaitu pada tingkatan yang mengenai seluruh wilayah negara. ${ }^{29}$

\section{Pengertian Hak Menguasai Dari Negara}

Pertama kali istilah dikuasai oleh negara (sebagai organisasi kekuasaan seluruh rakyat) dapat dibaca dalam Pasal 33 ayat (3) UUD 1945. Namun dalam penjelasan Pasal 33 ayat (3) tersebut tidak dijelaskan apa yang dimaksud dengan istilah 'menguasai' tersebut dan sampai berapa jauh yang ingin dicakupnya.

Pasal 2 ayat (2) UUPA telah mengembangkan pengertian tersebut sehingga kita merasakan sebagai suatu perubahan total dari pernyataan Domein yang pernah dikenal di tanah air sejak tahun 1870 yang oleh Belanda untuk membenarkan penjajahannya dan menguasai tanah-tanah di Indonesia. Belanda mengatakan oleh karena raja-raja di Indonesia telah takluk kepada pemerintahan Belanda, dan raja-raja di indonesia adalah 'pemilik' dari tanah-tanah di Indonesia maka dengan demikian tanah-tanah tersebut menjadi 'milik' dari pemerintah Belanda. Pernyataan domein itu ialah; jika tidak dibuktikan dengan hak eigendom, maka tanah-tanah. itu adalah domein (milik) dari negara. ${ }^{30}$
Di dalam Pasal 2 ayat (1) UUPA disebutkan: "Atas dasar ketentuan dalam Pasal 33 ayat (3) UUD dan hal-hal sebagai yang dimaksud dalam Pasal 1, bumi, air dan ruang angkasa, termasuk kekayaan alam yang terkandung di dalamnya itu pada tingkatan tertinggi di kuasai oleh Negara, sebagai organisasi seluruh rakyat Indonesia".

Sedangkan Pasal 2 ayat (2) berbunyi: Hak menguasai dari Negara termaksud dalam ayat (1) memberi wewenang untuk: (1) Mengatur dan menyelenggarakan peruntukan, penggunaan, persediaan dan pemeliharaan bumi, air dan ruang angkasa tersebut. (2)Menentukan dan mengatur hubungan-hubungan hukum antara orang-orang dengan bumi, air dan ruang angkasa. (3) Menentukan dan mengatur hubungan-hubungan hukum antara orangoang dan perbuatan-perbuatan hukum yang mengenai bumi, air dan rauang angkasa.

Dalam memori penjelasan ketentuan ini digolongkan pada ketentuan dasar Nasional Hukum Agraria yang baru. Hak menguasai dari negara itu tidak saja didasarkan atas ketentuan Pasal 1 dimana negara dianggap sebagai organisasi rakyat, sebagai alat bangsa tetapi dicarikan juga dasar hukumnya pada ketentuan Pasal 33 ayat (3) UUD 1945.31

Dengan demikian maka Pásal 2 UUPA memberikan sekaligus tafsiran resmi, interpretasi otentik mengenai arti perkataan "dikuasai" yang dipergunakan di dalam Pasal 33 ayat (3) UUD 1945 itu. Sebelum UUPA ada sementara orang yang menafsirkan perkataan "dikuasai" itu sebagai "dimiliki", tetapi UUPA dengan tegas menyatakan bahwa perkataan tersebut bukan berarti dimiliki. Bahkan pengertian domein

\footnotetext{
${ }^{29}$ Boedi Harsono, Hukum Agraria Indonesia, Jilid I bagian I, (Jambatan, Jakarta, 1983), hlm. 28.

${ }^{30}$.A.P. Parlindungan, Aneka Hukum Agraria, (Alumni, Bandung, Cet. 1, 1983), hlm.3.

31. Ibid, hIm. 4
} 
negara dihapuskan oleh UUPA. "Asas Domein" tidak dikenal dalam UUPA yang baru, demikian Memori Penjelasan Angka II/2.32

Notonegoro, memberikan uraian tentang Hak Menguasai Negara sebagai berikut : istilah yang perlu kita perhatikan pada pasal ini ialah istilah "dikuasai" dan "dipergunakan". Dengan tanpa lebih dahulu mempunyai purbasangka tentang penafsiran istilah-istilah ini, maka berdasarkan kenyataan terdapatnya dua macam istilah "dikuasal" dan "dipergunakan" dalam pasal ini, dapatlah ditarik kesimpulan bahwa harus diperbedakan antara "dikuasai" dan "dipergunakan" dalam arti bahwa "dipergunakan" itu sebagai tujuan terhadap "dikuasai", meskipun kata penghubungnya "dan" hingga nampaknya sebagai dua hal yang tidak ada sangkut pautnya dalam hubungan sebab akibat. Maksudnya ialah, bahwa "diper-gunakan" itu merupakan suatu pemyataan, yang termasuk di dalam perkataan "dikuasai". Kalau tidak ditassirkan demikian, maka situasinya tentu lain, ialah "dipergunakan" tidak termasuk di dalam "dikuasai", sehingga dengan demikian terdapat kemungkinan untuk -menafsirkan ini di dalam bentuk: Negara menguasai pemakaian tanah, sedang jika ditafsirkan "dipergunakan" itu termasuk "dikuasai", maka bentuk lalu; negara menguasai tanah. Yang memberi keputusan dalam hal ini ialah kata penghubung "dan". Apakah kata penghubung "dan" itu dapat dipertahankan di dalam artinya, kalau "diper-gunakan" kita masukkan ke dalam "dikuasai" ? Jadi, dengan demikian ada hubung-an sebab akibat. ${ }^{33}$
A.P. Parlindungan ${ }^{34}$ menyatakan dengan demikian negara sebagai organisasi kekuasaan "mengatur" sehingga membuat peraturan, kemudian "menyelenggarakan" artinya melaksanakan (execution) atas penggunaan/ peruntukan (use), persediaan (reservation), dan pemeliharaannya (maintenance) dari bumi, air, ruang angkasa dan kekayaan alam yang terkandung di dalamnya. Juga untuk menentukan dan mengatur (menetapkan dan membuat peraturan-peraturan) hak-hak apa saja yang dapat dikembangkan dari hak menguasai dari negara tersebut.

Lebih lanjut beliau menjelaskan; dari sikap ini jelaslah bahwa wewenang agraria dalam sistem UUPA adalah pada pemerintah sentral dan pemerintah daerah tidak boleh melakukan tindakan kewenangan agraria jika tidak ditunjuk ataupun didelegasi wewenang oleh pemerintah kepada daerah-daerah otonom, ataupun lembaga pemerintahan atau kepada departemen tertentu, ataupun kepada masyarakat hukum adat sebagaimana diperjelas oleh ayat (4) Pasal 2 ini dan semuanya akan dituangkan dalam peraturan tertentu.

Dari uraian di atas dapat ditarik kesimpulan bahwa daerah-daerah otonom atau lembaga kenegaraan ataupun departemen, serta kabupaten/kota dan kecamatan ataupun desa tidak dapat membuat peraturan-peraturan atau kebijaksanaan yang menyang-kut keagrariaan (pertanahan), kecuali didelegasi oleh pemerintah pusat. ${ }^{35}$

Jadi tiga kata-kata dikuasai oleh negara
32. Eddy Ruchiyat, Log cit, hlm. 9.
33 Notonagoro, Op Cit, hlm. 106-107.
${ }^{34}$ A.P. Parlindungan, Komentar Atas UUPA, Op. Cit,
${ }^{35}$ Roestandi Ardiwilaga, Hukum Agraria Indonesia, (N.V. Masa Baru, Bandung, 1962), hlm. 75. 
itu telah memberikan suatu pengertian yang sama sekali berlainan dari pernyataan domein negara tersebut, karena negara merasa bukan pemillik dari bumi, air dan ruang angkasa, tetapi mendudukkan posisinya dalam hubung-annya dengan bumi, air dan ruang angkasa dikaitkan sebagai organisasi kekuasaan negara. Tentunya harus ada satu organisasi yang melaksanakan tugas-tugas tersebut, dan tidak lain dari pemerintah Republik Indonesia sebagai pemerintah yang sah. ${ }^{36}$

Sebagai konsekuensi dari pernyataan bahwa hak menguasai oleh Negara tidaklah sama dengan pemyataan domein, maka selain pembatasan yang dibuat oleh Pasal 2 ayat (2) UUPA dapat dikonstruksikan dalam pengertian politis yaitu : (a) Konstatasi hak seseorang atau badan yaitu melalui lembaga konversi atas tanahtanah eks BW dan eks Hukum Adat dan atau tanah-tanah yang dikuasai oleh pemerintah daerah otonom ataupun yang dikuasai oleh lembaga-lembaga pemerintahan. (b)

Memberikan hak-hak baru yang ditetapkan oleh UUPA seperti hak milik, hak guna usaha, hak guna bangunan, hak pakai dan hak pengelolaan.

(c) Mengesahkan suatu perjanjian yang diperbuat antara seseorang pemegang hak milik dengan orang lain untuk menimbulkan suatu hak lain di atasnya, seperti yang kita kenal Hak Guna Bangunan di atas Hak Milik dan Hak Pakai di atas Hak Milik. ${ }^{37}$

Lebih lanjut A.P. Parindungan menjelaskan bahwa selain dari konstruksi di atas, juga dimungkinkannya organisasi kekuasaan ini untuk: (a) memberikan hak-hak keperdataan, baik kepada perseorangan ataupun badanbadan hukum privat, seperti Hak Milik, Hak Guna
Usaha, Hak Guna Bangunan dan Hak Pakai; ataupun (b) mengakui suatu hukum publik yang sudah ada sebelum-nya, seperti Hak Ulayat masyarakat-masyarakat hukum adat (Pasal 3 UUPA), maupun (c) memberikan hukum publik yang, baru, yaitu Hak Pengelolaan yang diberikan kepada lembaga-lembaga pemerintahan ataupun perusahaanperusahaan negara/daerah. dari hak pengelolaan ini dapat diberikan oleh pemegang Hak Pengeiolaan ini Hak Milik, $H G B$, dan Hak Pakai, dan akhirnya dari Hak Menguasai dari Negara ini; (d) dapat diberikan Hak Pakai (khusus) yaitu hak pakai yang tidak terbatas waktunya dan diberikan untuk pelaksanaan tugasnya, seperti Hak Pakai untuk Perwakilan Negara-negara asing, untuk kepentingan lembaga pemerin-tahan (seperti untuk bangunan pendidikan dan șeterusnya) dan untuk kepentingan sosial dan keagamaan.

\section{Penguasaan Negara Atas Sumberdaya Agraria}

\section{Bahan-bahan Galian}

\section{a) Dasar Penguasaan}

Pasal 1 Undang-undang Nomor 11 tahun 1967 tentang Pokok-pokok Pertambangan menetapkan, bahwa semua bahan galian yang terdapat dalam wilayah hukum pertambangan Indonesia yang merupakan endapan-endapan alam sebagai karunia Tuhan Yang Maha Esa, adalah kekayaan nasional bangsa Indonesia dan oleh karenanya dikuasai dan dipergunakan oleh

\footnotetext{
${ }^{36}$.A.P. Parlindungan, op cit, hlm. 41.

${ }^{37} \mathrm{Ibid}, \mathrm{hlm} .41$.
} 
Negara untuk sebesar-besar kemakmuran rakyat.

Penetapan ini menjadi dasar bagi negara untuk menguasai semua bahan galian dengan sepenuh-penuhnya untuk kepentingan negara dan untuk sebesar-besar kemakmuran rakyat. Dasar penguasaan negara atas bahan-bahan galian yang diletakkan dalam Pasal 1 Undang-undang Pokok Pertambangan tersebut merupakan penegasan lebih lanjut dari ketentuan Pasal 33 ayat (3) Undang-Undang Dasar 1945 (Konstitusi Indonesia), yang secara jelasnya hub kedua pasal termaksud dapat dilukiskan sebagai berikut :

a. dengan Pasal 33 ayat (3) Undang-Undang dasar 1945 bangsa Indonesia memberi kekuasaan kepada Negara untuk mengatur, memelihara, dan menggunakan kekayaan nasional yang berupa kekayaan alam tersebut untuk sebesar-besar kemakmuran rakyat.

b. Dan dengan Pasal 1 Undang-Undang pokok Pertambangan ditetapkan, bahwa kekayaan alam yang dikuasakan kepada negara untuk digunakan sebesar-besar kemakmuran rakyat itu adalah semua bahan galian yang terdapat dalam wilayah Hukum Pertambangan Indonesia.

b) Prinsip-prinsip Pengusahaan

Dasar penguasaan negara yang ditetapkan dalam Pasal 1 Undang-Undang Pokok Pertambangan sesuai dengan uraian di atas memberikan penguasaan yang sangat luas kepada Negara untuk mengatur, mengusahakan pemanfaatan dan pengawasan atas bahan-bahan galian yang ada dalam bumi Indonesia. Di samping itu dalam dasar dalam penguasaan Negara tersebut terkandung pula prinsip-prinsip pengusahaan bahan galian sebagai berikut : a. bahwa pelaksanaan pemanfaatan kekayaan nasional berupa bahan galian tersebut untuk kepentingan negara dan untuk sebesar-besar kemakmuran rakyat, sesuai dengan dasar demokrasi ekonomi yang tercantum di dalam penjelasan Pasal 33 ayat (1) dan (2) Undang-undang Dasar 1945 antara lain:

(1) Produksi dikerjakan semua untuk semua di bawah pimpinan atau atau penilikana n g g o t a - a n g g o t a masyarakat. Kemakmuran masyarakatlah yang diutamakan dan bukan kemakmuran orang-seorang.

(2) Cabang-cabang produksi yang penting bagi negara dan yang menguasai hajat hidup orang banyak harus dikuasai oleh negara, dan hanya perusahaan yang tidak menguasai hajat hidup orang banyak boleh ditangan orang-seorang.

b. Berhubung negara hanya men- dapatkan penguasaan saja atas bahan-bahan galian yang harus dimanfaatkan untuk kepentingan negara dan kemakmuran rakyat semaksimal mungkin, maka yang dapat diberikan kepada para pengusaha pertambangan adalah kuasa usaha pertambangan atau singkatnya disebut dengan Kuasa Pertambangan. Pemberian Kuasa Pertambangan yang diberikan ini tidak meliputi hak-hak atas permukaan bumi.

c. Sehubungan dengan para pengusaha hanya mendapatkan Kuasa Pertambangan saja, maka para pengusaha tersebut tidak melakukan pekerjaan-pekerjaan pertambangan sebagai pemilik wilayahwilayah pertambangan yang bersangkutan, tetapi sebagai pemegang 


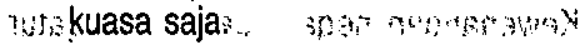
r: Oleh dkarena ritu : merekan hanya mendapatkan bagian hasilnya $a_{i}$ sebagai penggantij jasa yang telah: rdisumbangkan kepada negara dan bangsa: Indonesia: saja: Untuk itu perlu ditetapkan ketentuan-ketentuan tentang bagaimana bentuk dan besarnya penggantian jasa kepada para pengusaha pertambangan tersebut. mish antentsis:

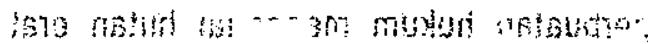
2. Penguasaan Negara atas Hutan

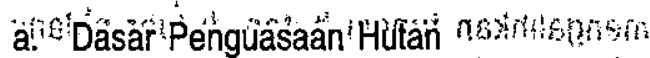

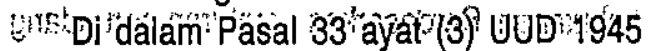

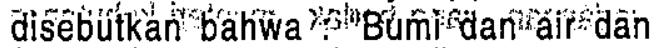

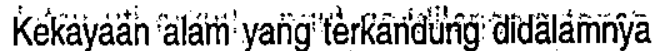

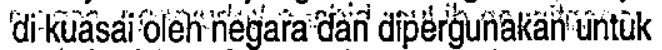
sebesar bsarnya kemákmuiran rảkyat?

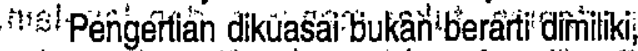

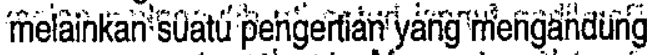

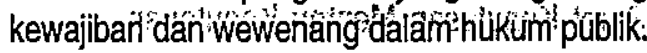

Hak negara dalam bidang kehutanan adalah benwenang unt $k_{k}$ (1) menetapkan dan mengatur perencanaan, peruntukan, penyediaan dan penggunaan hutan sesuai dengan fungsinya

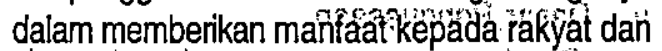

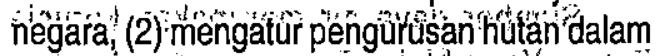

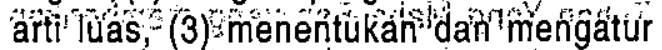

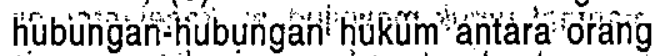
âtâu bâdân tiukum déngan "hưtan dân mengatur perbuatan perbuatan nükom

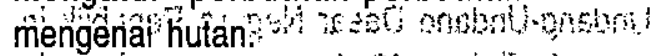

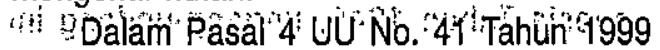
disebuitkan jưga tentang hak négara âtäs

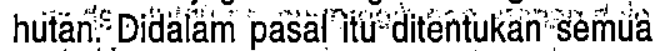
hutan đờa dâm wilayah Republik Indonêsia termâsuk kekäyaan alam yang terkandung

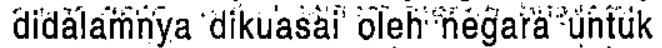
sébèsar-besar kemakmüran rảkyate maksud pengúa

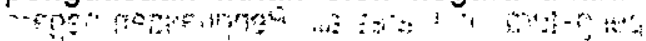

memberiswewenang kepada pemerintah untukio sur

1.: Mengatur dan mengurus segala sesuatu yang; berkaitan dengan hutan, kawasan hutan, dan hasil hutan. Tujuan pengurusan Hutan adalah. untuk rrmemperoleh manfaat yang sebesarisotbesarnya serta serba guna dan lestari in inuntuk kemakmuran-rakyat:

merengurusan hutan tersebut meliputi : (a) fur perencanaan kehutanan; (b) pengelolaan fos hutan; (c) penelitian dan pengembangan ringendidikan dan latihan pengolahan mxakehutanan, serta pengawasan:

2m:Menetapkan status wilayah tertentu ist sebagai kawasan hutan atau bukan nazkawasan hutan.Tujuan perencanaan

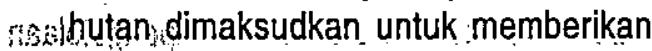
mipedoman dan arah yang menjamin huntercapainya tujuan penyelenggaraan nst kehutanan. Dimana perencanaan . hutan istotersebut meliputi: (a) inventarișasi hutan; Gun(b) pengukuhan kawasan hutan; (c) surpenatagunaan kawasan hutan; (d) Golpembentukan wilayah pengelolahan sorhutan dan penyusunan rencana sizkehutanan:

3.: mengatur dan menetapkan hubunganin hubungan hukum antara orang dengan is w hutan, siserta mengatur, perbuatan"is perbuatan hukum mengenai kehutanan.

Penguasaan ini tetap memperhatikan hak masyarakat shukum adat, . sepanjang kenyataannya $r$ masih ada dan diakui kebenarannyays serta tidak bertentangan dengan kepentingan nasional.

“., Selain itu; Pemerintah juga mempunyai wewenang untuk memberikan izin dan hak kepada pihak lain untuk melakukan kegiatan di bidang kehutanan. Namun demikian, untuk 
hal-hal tertentuyang sangatpenting, berskala, dan berdampak luas serta bemilai strategis, pemerintah harus memperhatikan aspirasi rakyat melalui persetujuan Dewan Perwakilan Rakyat.

\section{b. Perencanaan Hutan}

Di dalam Pasal 11 Undang-undang Nomor 41 Tahun 1999 diatur tentang peren-canaan hutan. Perencanaan dimaksud untuk -memberikan pedoman dan arah yang menjamin tercapainya tujuan penyelenggaraan kehutanan.

Perencanaan kehutanan dilaksanakan secara transparan, bertanggung-gugat, partisipatif, terpadu, serta memperhatikan kekhasan dan aspirasi daerah. Perencanaan kehutanan meliputi: (1) inventarisasi hutan; (2). pengukuhan kawasan hutan; (3) penatagunaan kawasan hutan; (4) pembentukan wilayah pengelolaan hutan, dan penyusunan rencana kehutanan.

Inventarisasi hutan dilaksanakan untuk mengetahui dan memperoleh data dan informasi tentang sumber daya, potensi kekayaan alam hutan, serta lingkungannya secara lengkap. Inventarisasi ïni dengan survei mengenai status dan keadaan fisik hutan, flora dan fauna, sumber daya manusia, serta kondisj sosial masyarakat di dalam dan sekitar kawasan hutan. Inventarisasi ini terdiri dari inventarisasi hutan tingkat nasional, tingkat wilayah, tingkat aliran sungai, dan tingkat unit pengelolaan. Inventarisasi hutan ini djjadikan dasar untuk :

1. pengukuhan kawasan hutan

2. penyusunan neraca sumber daya hutan

3. penyusunan rencana kehutanan

4. sistem informasi kehutanan.

Kewenangan lain dari negara dalam bidang kehutanan adalah mengatur hubungan hukum antara subjek hukum dengan hutan, dan perbuatan-perbuatan mengenai hutan.
Kewenangan negara dalam mengatur hubungan hukum antara subjek hukum dengan hutan dan kehutanan erat kaitannnya dengan kewenangan negara c.q. Menteri Kehutanan dalam memberikan izin terhadap subjek hukum yang memenuhi syarat-syarat yang telah ditentukan.

Kewenangan negara c.q menteri kehutanan dalam mengatur perbuatanperbuatan hukum mengenai hutan erat kaitannya dengan kewenangan menteri dalam mengalihkan fungsi hutan di luar bidang kehutanan. Berdasarkan peraturan perundangundangan yang berlaku menteri kehutanan dapat mengalihkan fungsi hutan itu untuk kepentingan di luar bidang kehutanan, seperti pelepasan hutan untuk transmigrasi, budi daya pertanian, tukar menukar, dan lain-lain. Peralihan fungsi hutan itu dituangkan dalam Surat Keputusan Menteri Kehutanan.

\section{Penguasaan Negara atas Sumberdaya Air}

\section{a. Dasar Penguasaan}

Sumber daya air merupakan karunia Tuhan Yang Maha Esa yang memberikan manfaat untuk mewujudkan kesejahteraan bagi seluruh rakyat Indonesia dalam segala bidang. Sejalan dengan Pasal 33 ayat (3) Undang-Undang Dasar Negara Republik Indonesia Tahun 1945, undang-undang ini menyatakan bahwa sumber daya air dikuasai oleh negara dan dipergunakan untuk sebesarbesar kemakmuran rakyat secara adil. Atas penguasaan sumber daya air oleh negara dimaksud, negara menjamin hak setiap orang untuk mendapatkan air bagi pemenuhan kebutuhan pokok sehari-hari dan melakukan pengaturan hak atas air. Penguasaan negara 
atas sumber daya air tersebut diselenggarakan oleh Pemerintah dan/atau pemerintah daerah dengan tetap mengakui dan menghormati kesatuan-kesatuan masyarakat hukum adat beserta hak-hak tradisionalnya, seperti hak ulayat masyarakat hukum adat setempat dan hak-hak yang serupa dengan itu, sepanjang masih hidup dan sesuai dengan perkembangan masyarakat dan prinsip Negara Kesatuan Republik Indonesia. ${ }^{38}$

\section{b. Pengaturan Sumberdaya Air}

Pengaturan hak atas air diwujudkan melalui penetapan hak guna air, yaitu hak untuk memperoleh dan memakai atau mengusahakan air untuk berbagai keperluan. Hak guna air dengan pengertian tersebut bukan merupakan hak pemilikan atas air, tetapi hanya terbatas pada hak untuk memperoleh dan memakai atau mengusahäkan sejumlah (kuota) air sesuai dengan alokasi yang ditetapkan oleh pemerintah kepada pengguna air, baik.untuk yang wajib memperoleh izin maupun yang tidak wajib izin. Hak guna air untuk memenuhi kebutuhan pokok sehari-hari, pertanian rakyat, dan kegiatan bukan usaha disebut dengan hak guna pakai air, sedangkan hak gùna air untuk memenuhi kebutuhan usaha, baik penggunaan air untuk bahan baku produksi, pemanfaatan potensinya, media usaha, maupun penggunaan air untuk bahan pembantu produksi, disebut dengan hak guna usaha air. ${ }^{39}$

Jumlah alokasi air yang ditetapkan tidak bersifat mutlak dan harus dipenuhi sebagaimana yang tercantum dalam izin, tetapi dapat ditinjau kembali apabila persyaratan atau keadaan yang dijadikan dasar pemberian izin dan kondisi ketersediaan air pada sumber air yang bersangkutan mengalami perubahan yang sangat berarti dibandingkan dengan kondisi ketersediaan air pada saat penetapan alokasi.

Pengusahaan sumber daya air pada tempat tertentu dapat diberikan kepada badan usaha milik negara atau badan usaha milik daerah bukan pengelola sumber daya air, badan usaha swasta dan/atau perseorangan berdasarkan rencana pengusahaan yang telah disusun melalui, konsultasi publik dan izin pengusahaan sumber daya air dari pemerintah. Pengaturan mengenai pengusahaan sumber daya air dimaksudkan untuk mengatur dan memberi alokasi air baku bagi kegiatan usaha tertentu. Pengusahaan sumber daya air tersebut dapat berupa pengusahaan air baku sebagai bahan baku produksi, sebagai salah satu media atau unsur utama dari kegiatan suatu usaha, seperti perusahaan daerah air minum, perusahaan air mineral, perusahaan minuman dalam kemasan lainnya, pembangkit listrik tenaga air, olahraga arung jeram, dan sebagai bahan pembantu proses produksi, seperti air untuk sistem pendingin 'mesin (water cooling system) atau air untuk pencucian hasil eksplorasi bahan tämbang. Kegiatan pengusahaan dimaksud tidak termasuk menguasai sumber airnya, tetapi hanya terbatas pada hak untuk menggunakan air sesuai dengan alokasi yang ditetapkan dan menggunakan sebagian sumber air untuk keperluan bangunan sarana prasarana yang diperlukan misalnya pengusahaan bangunan sarana prasarana. Pengusahaan sumber daya air tersebut dilaksanakan sesuai dengan

\footnotetext{
${ }^{38}$ Penjelasan Umum Undang-undang No. 7 tahun 2004 tentang Sumberdaya Air.

${ }^{39} \mathrm{lbid}$
} 
rambu-rambu sebagaimana diatur dalam norma, standar, pedoman, manual (NSPM) yang telah ditetapkan..$^{40}$

\section{Simpulan}

Adanya penguasaan oleh negara atas sumber-sumber agraria adalah sebagai konsekuensi/implementasi dari Pasal 33 ayat (3) UUD 1945. Dasar konsepsi ini adaiah pemberian kuasa dari bangsa Indonesia kepada Negara sebagai organisasi tertinggi dari seluruh rakyat Indonesia. Pemberian 'kuasa' untuk menguasai sumber daya agraria ini semata-mata untu kepentingan pemberi kuasa yaitu rakyat Indonesia dengan tujuan untuk sebesar-besar kemakmuran rakyat.

\section{Daftar Pustaka}

Abrar Saleng, 2004. Hukum Pertambangan, Ull Press, Yogyakarta.

A.P. Parlindungan, 1991. Komentar Atas Undang-Undang Pokok Agraria, PT. Mandar Maju, Bandung.

A.P. Parlindungan, 1983. Aneka Hukum Agraria, Alumni, Bandung, Cet. I.

Boedi Harsono, 1997. Hukum Agraria Indonesia, Sejarah Pembentukan Undangundang Pokok Agraria, Isi dan Pelaksanaannya, Jilid 1, Ctk Ketujuh, Edisi Revisi 1997, Djambatan, Bandung.

Boedi Harsono, 1983. Hukum Agraria Indonesia, Jilid I bagian I, Jambatan, Jakarta.

Dianto Bachriadi,et.al. 1997. Perubahan Politik, Sengketa, dan Agenda Pembaruan Agraria di Indonesia: Reformasi Agraria, KPA bekerjasama dengan Lembaga Penerbit Fakultas Ekonomi Universitas Indonesia, Jakarta.

Kuntowijoyo, 1992. "Masalah Tanah dan Runtuhnya Mitos Negara Budiman", Makalah, Yogyakarta,

Maria R. Ruwiastuti, Noer Fauzi, Dianto Bachriadi, 1997. Penghancuran Hak Masyarakat Adat Atas Tanah, KPA, Bandung.

Moh. Koesnoe, 1979. Catatan-catatan Terhadap Hukum Adat Dewasa Ini, Airlangga University Press, Surabaya.

Noer Fauzi, 1999. Petani \& Penguasa, Dinamika Perjalanan Politik Agraria Indonesia, Insist Press, KPA dan Pustaka Pelajar, Yogyakarta.

Noer Fauzi, 2001. Restitusi Hak Atas Tanah, Mewujudkan Keadilan Agraria di Masa Transisi, Kertas Posisi KPA (Position Paper) No. 009/2001, KPA, Bandung.

Noer Fauzi, Dianto Bachriadi, 2001. Hak Menguasai dari Negara (HMN), Persoalan Sejarah yang Harus Diselesaikan, Kertas Posisi KPA (Position Paper) No.004/1998, Ctk. Ke-2 tahun 2001.

Notonagoro, 1984. Politik Hukum dan Pembangunan Agraria di Indonesia, Bina Aksara, Jakarta.

Roestandi Ardiwilaga, 1962. Hukum Agraria Indonesia, N.V. Masa Baru, Bandung.

Ronald Z. Titahelu, 1993. "Penetapan AzasAzas Hukum Umum Dalam Penggunaan Tanah Untuk SebesarBesar Kemakmuran Rakyaf', Disertasi, PPs.UNAIR, Surabaya.

Rony Hanitijo Soemitro, 1994. Metodologi 
Penelitian Hukum dan Jurimetri, Ghalia Indonesia, Jakarta.

R. Soepomo, 1970. Hubungan Individu dan Masyarakat dalam Hukum Adat, PT. Pradnya Paramita, Jakarta.

.Satjpto Rahardjo, 1986. Imu Hukum, Alumni, Bandung.

Soediman Kartohadiprodjo, 1979. Membina Tata Kehidupan Politik Berdasarkan Undang-Undang Dasar 1945, Alumni, Bandung, , Cet.I.

Soerjono Soekanto, 1982. Sosiologi Hukum Dalam Masyarakat, CV. Rajawali, Jakarta.

Soetikno, 1976. Filsafat Hukum,. Bagian I, Pradnya Paramita, Jakarta, Cet. 1. Sudikno Mertokusumo, 1986. Mengenal
Hukum (Suatu Pengantar), Liberty, Yogyakarta.

Ter Haar, 1976. Asas-asas dan Susunan Hukum Adat, terjemahan K.Ng. Soebekti Poesponoto, Pradnya. Paramita, Jakarta.

Van L.J. Apeldoorn, 1978. Pengantar IImu Hukum, terjemahan Oetarid Sadino, Penerbit PT. Pradnya Paramita, Jakarta. Undang-Undang Dasar 1945 Undang-Undang No. 5 Tahun 1960 tentang Peraturan Dasar Pokok-pokok Agraria

Undang-Undang No. 11 Tahun 1967 tentang Ketentuan-Ketentuan Pokok Pertambangan Undang-Undang No. 41 Tahun 1999 tentang Kehutanan 